\title{
Morphological characterization and sex-related differences of the mandible of the armadillos Chaetophractus vellerosus and Zaedyus pichiy (Xenarthra, Dasypodidae), with consideration of dietary aspects
}

\author{
Nora S. Sidorkewicj ${ }^{1} \&$ Emma B. Casanave ${ }^{1,2}$ \\ 1. Departamento de Biología, Bioquímica y Farmacia, Universidad Nacional del Sur, 8000 Bahía Blanca, Argentina. (norasidorke@bvconline.com.ar) \\ 2. CONICET, Argentina.
}

\begin{abstract}
The morphological characteristics of the mandible of adult Chaetophractus vellerosus (Gray, 1865) and Zaedyus pichiy (Desmarest, 1804) were studied to establish its generalized design and to identify inter- and intra- (sexual) specific differences. Morphological descriptions were complemented with the application of univariate and multivariate (analysis of correlation matrices, PCA, discriminant analysis) techniques. The mandible of both species is very similar, and is characterized by elevated condyle, well developed angular process, distinct coronoid process, tooth row which extends to the rear end of the angle between body and ramus, and unfused but firm symphysis. Although both armadillos are omnivorous, a more slender configuration of the jaw in Z. pichiy could be indicative of a better adaptation of its masticatory apparatus to insectivory. The PCA showed an almost total segregation of both species on PC1 (47.7\% of the total variance), with C. vellerosus being associated to mandibles taller and with wider body and ramus. Zaedyus pichiy was characterized by heavy loadings of length parameters on PC2 (22.6\% of the variance). A small degree of sexual dimorphism was found, with size-based differences in C. vellerosus (larger mandibles in females) and shape-based differences in Z. pichiy (taller mandibles in males, longer ones in females). Correlations between variables were higher in males of both species, indicating a more stable shape of the mandible than in females. The selected parameters to discriminate sexes were the body length of the mandible in C. vellerosus (correct classification: ca. $86 \%$ in males, $81 \%$ in females), and the height of the mandible at the level of the last tooth in Z. pichiy (near $85 \%$ of right assignment in both sexes). The inclusion of a new variable (body length) in the latter species improved the classification of the females to $100 \%$. Teeth are typically 10 in C. vellerosus and 9 in Z. pichiy, but aberrancies in this basic number, such as unilateral or bilateral extra or fewer teeth, are common.
\end{abstract}

KEYWORDS. Cingulata, masticatory apparatus, morphometry, screaming hairy armadillo, pichi.

RESUMEN. Caracterización morfológica y diferencias sexuales en la mandíbula de los armadillos Chaetophractus vellerosus y Zaedyus pichiy (Xenarthra: Dasypodidae), con consideración de aspectos dietarios. Se estudiaron las características morfológicas de la mandíbula de adultos de Chaetophractus vellerosus (Gray, 1865) y Zaedyus pichiy (Desmarest, 1804), a fin de establecer su diseño generalizado y de identificar diferencias inter e intraespecíficas. Las descripciones morfológicas se complementaron con técnicas univariadas y multivariadas (análisis de matrices de correlación, ACP, análisis discriminante). La mandíbula es similar en ambas especies, y se caracteriza por cóndilo elevado, proceso angular bien desarrollado, proceso coronoides pronunciado, hilera dentaria que se extiende hasta el ángulo mandibular, y sínfisis no fusionada pero firme. La mandíbula de Z. pichiy es más esbelta y delicada que la de C. vellerosus, lo que podría indicar mayor adaptación del primero a hábitos insectívoros, a pesar de la omnivoría general en la que incursionan ambas especies. El ACP permitió observar una segregación casi total de las dos especies sobre CP1 (47,7\% de la varianza total), con C. vellerosus asociado a mayores valores de ancho de rama ascendente, ancho de rama horizontal y altura mandibular. Zaedyus pichiy se asoció a valores elevados de longitud mandibular sobre CP2 (22,6\% de la varianza). El dimorfismo sexual es leve en ambas especies; en C. vellerosus quedó definido por un factor tamaño, con mandíbulas mayores en las hembras, mientras que en Z. pichiy se verificaron diferencias de forma, con mandíbulas más altas en los machos y más largas en las hembras. Las correlaciones entre variables fueron más elevadas en los machos que en las hembras de ambas especies, indicando una mayor estabilidad en la forma mandibular de los primeros. Los parámetros seleccionados para la discriminación sexual fueron la longitud del cuerpo mandibular en C. vellerosus (aproximadamente $86 \%$ de clasificación correcta en machos, $81 \%$ en hembras), y la altura a nivel del último molariforme en $Z$. pichiy (cerca de $85 \%$ de clasificación correcta en ambos sexos). La inclusión de otra variable (longitud del cuerpo) en la última especie mejoró la clasificación de las hembras al 100\%. Los dientes son típicamente 10 en C. vellerosus y 9 en Z. pichiy, pero las anomalías en este número básico, consistentes en carencias o excesos dentarios unilaterales o bilaterales, son frecuentes.

PALABRAS-CLAVE. Cingulata, aparato masticador, morfometría, piche llorón, pichi.

The screaming hairy armadillo Chaetophractus vellerosus (Gray, 1865) and the pichi Zaedyus pichiy (Desmarest, 1804) belong to the most widespread and diverse xenarthran group, the family Dasypodidae (Order Cingulata). Both species have a large distribution in South America, from where they are native, and are particularly abundant in Argentina and Chile (REDFORD \& EisENBERG, 1992; Wetzel et al., 2007), coexisting in some areas of their distributional range (ABBA \& VIZCAíno, 2011).

The body dimensions (size and mass) of $C$. vellerosus and $Z$. pichiy are in the same order of magnitude. Although it is known that the skull size is similar in both species, little is known about the cranial morphology thereof. The scarcity of comparative data on the cranial structures of these species, mainly in the masticatory apparatus, prompts the completion of studies that aids to establish their main diagnostic characteristics.

Studies on the morphology of the mandibulodental complex of the Cingulata-armadillos, pampatheres and glyptodonts -, some of them including biomechanical aspects, are available for several fossil forms (e.g. VizCAÍNo et al., 1998, 2004, 2006; De IuLiIs et al., 2001), but fewer data for extant armadillos are known despite their great ecological diversity. SMITH \& REDFORD (1990) carried out a morphological and functional comparative study of the feeding structures of Euphractus sexcinctus (Linnaeus, 1758) and Dasypus novemcinctus Linnaeus, 1758 concluding that, although jaw morphology reflects 
the dietary diversity of each species, it may be difficult to predict accurately behaviour or diet on the basis of morphology, even after comparison with other species with analogous morphological adaptations. WIBLE \& GAUDIN (2004) performed an exhaustive morphological characterization of the mandible of $E$. sexcinctus as part of a bone-by-bone description of the skull, and they made comparisons with other xenarthrans and nonxenarthrans taxa in order to place the cranial osteology of this species in a phylogenetic context. SQUARCIA et al. (2006) performed a morphological description of the mandible of Chaetophractus villosus; subsequent work demonstrated the existence of sexual dimorphism in the mandible of this species, being females the larger sex (SQUARCia et al., 2009).

The aim of the present study was threefold: (i) to perform a detailed morphological description of the mandible of Chaetophractus vellerosus and Zaedyus pichiy; (ii) to carry out a morphometric study to examine if there exist inter- and intra- (sexual) specific differences; and (iii) to predict possible differences in the diet of both species based on the morphological characteristics observed for the mandible. It is hoped that this study will provide valuable information to help fill gaps in the knowledge of this group.

\section{MATERIALS AND METHODS}

Material was taken from the dasypodid's collection of the Laboratorio de Anatomía Comparada, Departamento de Biología, Bioquímica y Farmacia, Universidad Nacional del Sur (UNS), Bahía Blanca, Argentina.

For the quantitative analysis, left mandibles of 30 specimens of $C$. vellerosus (14 males, 16 females) and of 26 specimens of $Z$. pichiy (13 males, 13 females) were used. To minimize measurement errors in the quantitative analysis, jaws were coordinated on a graph paper between horizontal and vertical lines. Horizontal tangent lines were taken at the maximum ventral convexity of the body, the tip of the coronoid process, and the tip of the condylar process. Vertical tangent lines were taken at the most salient rostral and caudal points. Measurements were performed with digital callipers $(0.01 \mathrm{~mm})$ over lineal projections on the graph paper (Fig. 1) to record four lengths and four heights: total length (TL); body length (BL); length of the dental series (LDS); ramus width (RW); total height $(\mathrm{TH})$; condylar height $(\mathrm{CH})$; and height at the level of the first tooth (HFT) and at the last tooth (HLT).

Mean values of the measured traits were compared between species and between sexes by means of Student's one-tailed t-test ( $\mathrm{p} \leq 0.05$ ), prior testing of the data for normality and homogeneity of variances (Kolmogorov-Smirnov and Lilliefors tests, respectively; $p>0.10)$. In case of differences in the size of the mandible between males and females, an ANCOVA $(p \leq 0.05)$ was applied to check the presumed relationships between TL and the total length of the skull (TLS, anterior edge of the premaxilla to the posteriormost point of the nuchal crest). Morphological data were analyzed for the total sample and for males and females of each species by principal component analysis (PCA) using InfoStat software (INFOSTAT, 2006). The correlation matrices of both genders were analyzed separately to evaluate the relationship between the measured variables. For each species, a stepwise discriminant analysis was carried out to obtain a function to separate sexes using program $7 \mathrm{M}$

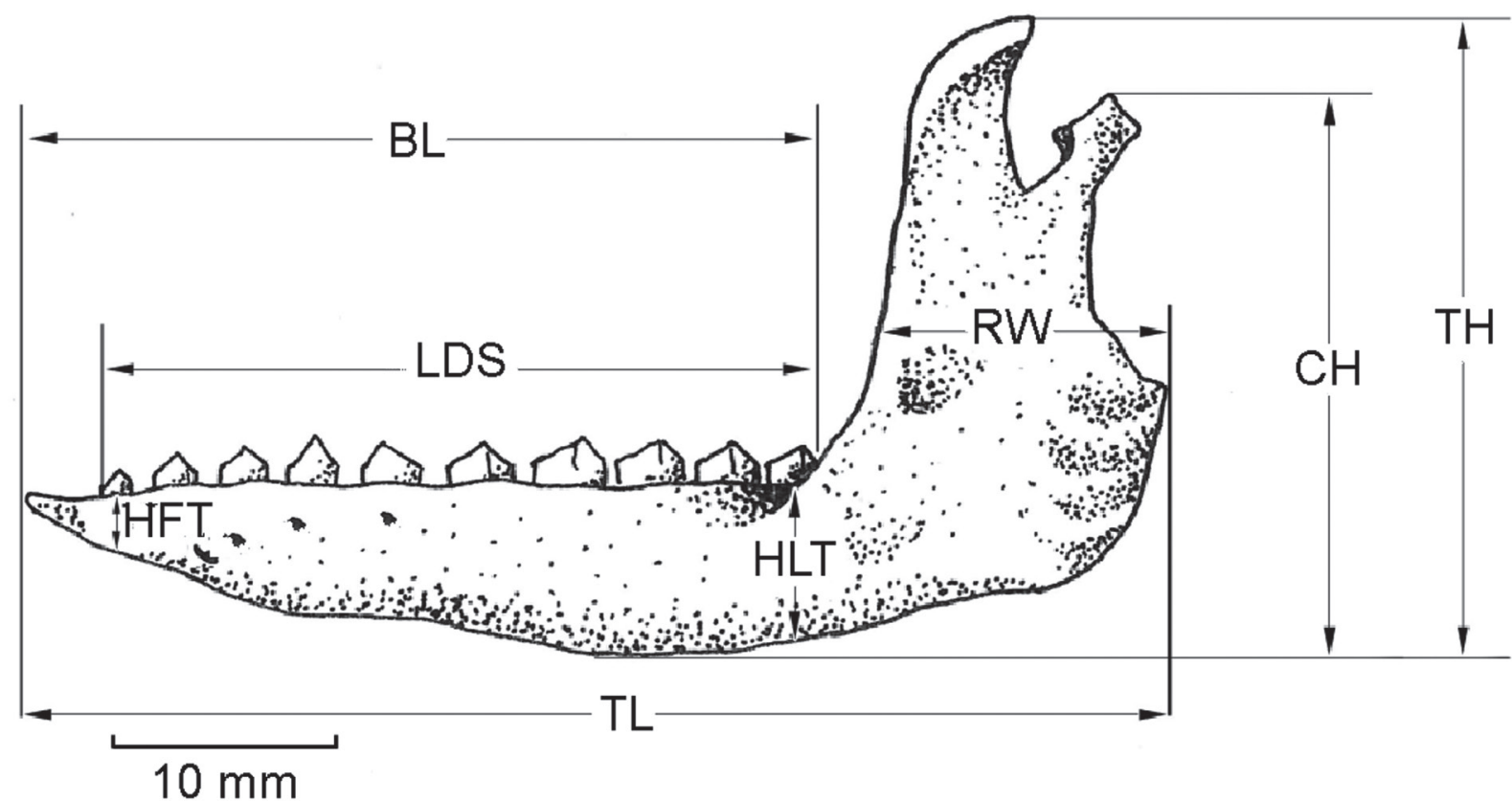

Fig. 1. Measurements taken from the left mandibles in Chaetophractus vellerosus (Gray, 1865) and Zaedyus pichiy (Desmarest, 1804) (BL, body length; $\mathrm{CH}$, condylar height; HFT, height at the level of the first tooth; HLT, height at the level of the last tooth; LDS, length of the dental series; RW, ramus width; TH, total height; TL, total length). 
of the BMDP statistical package (JENNRICH \& SAMPSON, 1983). The individuals were classified according to the function obtained and the percentages of right assignment were calculated.

Material examined: collected in Buenos Aires province, ARGENTINA, between $37^{\circ} 41^{\prime}-38^{\circ} 46^{\prime} \mathrm{S}$ and $61^{\circ} 21^{\prime}-62^{\circ} 44^{\prime} \mathrm{W}$ Chaetophractus vellerosus: 140 (UNS CVEMA3, 19.VI.1991; UNS CVEMA4, 25.VI.1991; UNS CVEMA5, 06.IV.1992; UNS CVEMA6, 05.VIII.1992; UNS CVEMA9, 16.XI.1993; UNS CVEMA11, 28. XI.1993; UNS CVEMA13, 02.X.1994; UNS CVEMAN1, 18.X.1994; UNS CVEMA17, 03.XI.1994; UNS CVEMA25, 17.V.1995; UNS CVEMA73, 13.III.1998; UNS CVEMA74, 08.V.1998; UNS CVEMA78, 14.VII.2000; UNS CVEMA79, 08.VIII.2000); 16 ㅇ (UNS CVEHA1, 01.II.1991; UNS CVEHA2, 20.III.1991; UNS CVEHA7, 13.X.1991; UNS CVEHA8, 16.VII.1993; UNS CVEHA12, 18.XI.1993; UNS CVEHA14, 25.XI.1993; UNS CVEHA16, 30.XI.1993; UNS CVEHA18, 02.XII.1993; UNS CVEHA19, 01.IV.1994; UNS CVEHA20, 01.IX.1994; UNS CVEHA22, 06.VII.1995; UNS CVEHA23, 08.VIII.1995; UNS CVEHA24, 08.XII.1995; UNS CVEHA26, 15.VIII.1996; UNS CVEHAA4, 03.VI.1998; UNS CVEHA76, 14.VII.1998). Zaedyus pichiy: $13{ }^{\lambda}$ (UNS ZPMA1, 13.IX.1989; UNS ZPMA3, 04.VIII.1990; UNS ZPMA4, 27.VI.1991; UNS ZPMA5, 03.VII.1991; UNS ZPMA6, 17.XII.1992; UNS ZPMA8, 10.VIII.1993; UNS ZPMA9, 04.IX.1993; UNS ZPMA10, 19.III.1995; UNS ZPMA11, 23.III.1995; UNS ZPMA12, 16.XI.1995; UNS ZPMA14, 24.IV.1996; UNS ZPMA15, 30.V.1997; UNS ZPMA51, 05.X.1997); 13 ㅇ (UNS ZPHA1, 02.VII.1993; UNS ZPHA2, 26.VIII.1993; UNS ZPHA3, 16.XI.1993; UNS ZPHA4, 02.IV.1994; UNS ZPHA7, 07.III.1995; UNS ZPHA11, 17.IV.1995; UNS ZPHA12, 17.VIII.1995; UNS ZPHA13, 24.IV.1996; UNS ZPHA16, 28.X.1997; UNS ZPHA17, 28.X.1997; UNS ZPHA52, 14.VII.2000; UNS ZPHA53, 14.VII.2000; UNS ZPHA54, 08.VIII.2000)

\section{RESULTS}

Morphology. The mandible is formed by a solid dentary whose shape is similar in both species, but with a general massive constitution in the screaming hairy armadillo (Figs 2-17). The angle between the two portions of the mandible, the body and the ramus, is nearly right in $C$. vellerosus and slightly obtuse in Z. pichiy. The body, narrower and sharper in the pichi, is elongated in both species as a consequence of the enlargement of the rostrum; the maximum ventral convexity locates at its caudal third. Its outer surface is quite smooth, whereas the inner one is furrowed by small grooves that are more marked in C. vellerosus. In lateral view, the body is perforated by several minute holes, the most conspicuous of which are the mental foramina. The number and exact position of these foramina can vary between individuals of each species, but they are generally four and locate between the level of the second and the fifth alveoli in the screaming hairy armadillo (Figs 2-5), and between the first and fourth alveoli in the pichi (Figs 6-9).

The tooth row is arranged along almost the entire length of the body, with only a small edentulous fraction at its rostral end which is larger in Z. pichiy. The posterior-most tooth is partly hidden by the base of the coronoid process in lateral view. The characteristic number of mandibular teeth is 10 in the screaming hairy armadillo and 9 in the pichi, however some variability in this basic number has been observed in adult individuals of both species. We have encountered three specimens of $C$. vellerosus with anomalies in their dental formula, a female with 8 teeth in its left mandible, another female with 10 alveoli but only 9 erupted teeth (second tooth did not erupted) in its left mandible, and a male whose first 2 teeth did not erupted in any of the jaws. For $Z$. pichiy, seven individuals were found with extra or less teeth at the rostral end of the dental series, affecting only one (left or right) of their mandibles: four individuals with 10 teeth (three females, left mandible; one male, right mandible), and three individuals with 8 teeth (one female, left mandible; one male, right mandible; one male, left mandible). The presence of a scaffolding bony material was observed filling all the alveoli of unerupted teeth. None of these aberrant specimens, which were deposited in the examined collection, were included in the quantitative analysis.

The teeth have the characteristic conformation of the group, i.e. they are simple, cylindrical, high-crowned and open-rooted. Their shape is ovate, with the major axis oriented rostro-caudally. The teeth size (height and crossed diameters) increases from the first to the sixth tooth in C. vellerosus (Figs 2-5) and to the fifth tooth in Z. pichiy (Figs 6-9), and then decreases. In the juveniles of both species, teeth are conical, but owing to differential tooth wear of hard outer and softer inner layers of dentine (based on Ferigolo, 1985), sharplyedged cutting margins on their lingual and labial sides arises through life. In both species, these sharp edges form in all teeth excepting the first one, but crests are most pronounced from the sixth to the eighth tooth.

The mandibular ramus, wider than the body, is elevated and their three processes (coronoid, condylar, angular) lye dorsal to the tooth row level. The coronoid process, taller than the condyle, resembles the dorsal fin of a shark, with the tip pointing caudally; it is wider in C. vellerosus (Figs 2-5) than in Z. pichiy (Figs 6-9). In both species, the rostral border of the coronoid process has a well developed ridge for the insertion of the temporalis muscle. The condyle is separated from the coronoid process by a deep mandibular notch. The articular surface of the condyle is gently concave and rectangular, with its major axis oriented medio-laterally; it locates on the top of a neck which is more elongated in $Z$. pichiy. The angular process is well developed in both species, but it is more expanded ventrally and caudally and has a more acute and dorsally-directed tip in the screaming hairy armadillo (Figs 2-5) than in the pichi (Figs 6-9). This process surpassed the condyle toward caudal except in female $Z$. pichiy. In the labial side of the mandible, both species have an ovoid depression at the base of the coronoid process. Along the ventral margin of the angular process and perpendicular to it, there are scars for the insertion of the masseter muscle which are decreasing in size from the surface inwards. The roughness and thickness of the edge of 
the angular process are greater in the screaming hairy armadillo. In medial view (Figs 10-17), the ramus has a conspicuous mandibular foramen for the inferior alveolar neurovascular bundle; it is located at the level of the alveolar plane, in the base of an ovoid concavity. The scars for the insertion of the pterygoid muscle are notorious.

The left and right dentaries are not fused but firmly joined anteriorly by a fibrous tissue, forming a mandibular symphysis that extends from the rostral tip to the caudal level of the third alveolus in C. vellerosus and of the second alveolus in Z. pichiy. The scars for fibrous attachment are deeper in the former species (Figs 10-13) than in the latter one (Figs 14-17).

Morphometry. The dimensions of the mandible of both species were similar, although mean values of almost all measured traits were significantly higher in C. vellerosus than in Z. pichiy, mainly for HLT (Tab. I). Sexual differences in jaw size were detected in $C$. vellerosus, females being the larger sex in most of

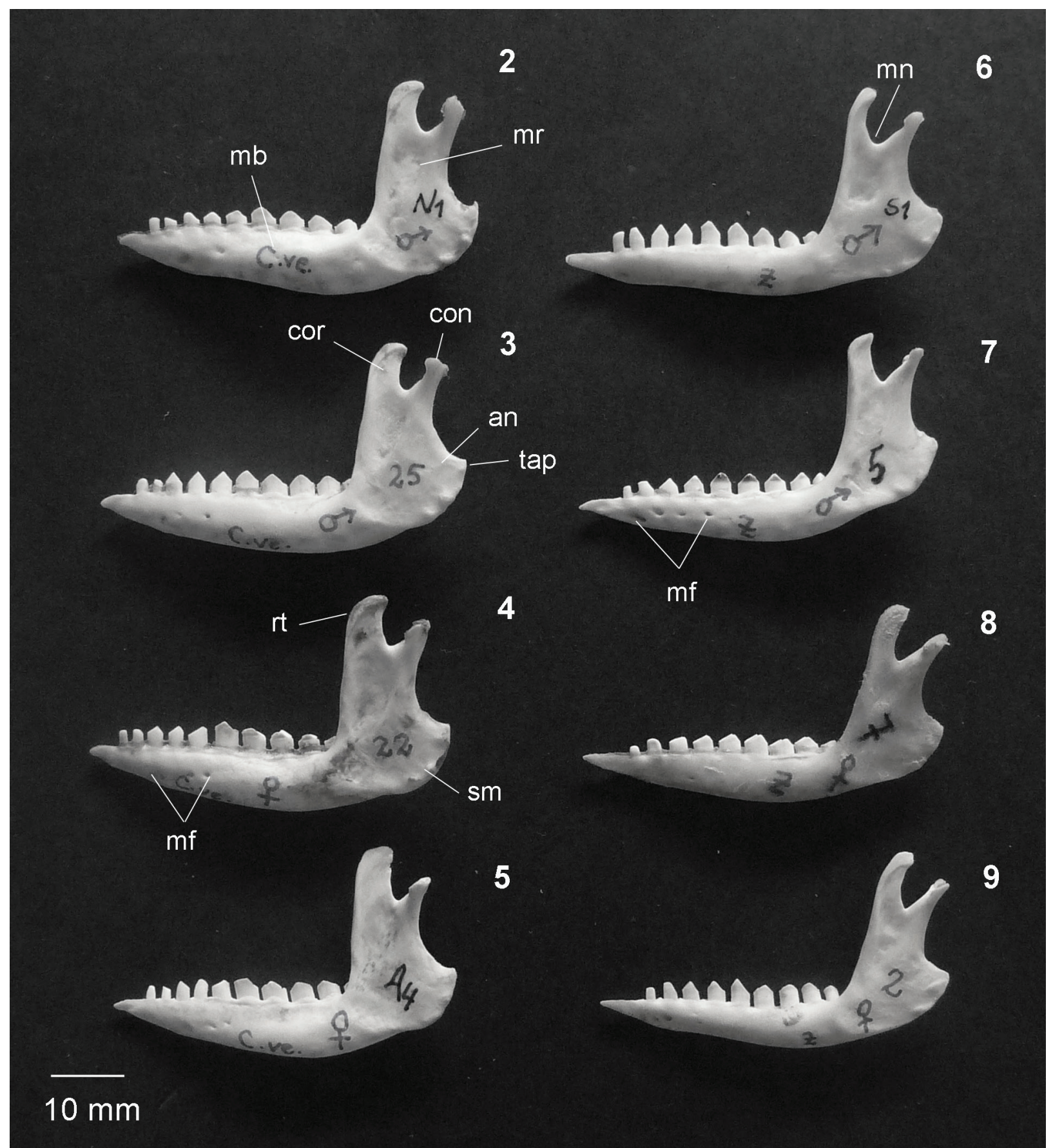

Figs 2-9. Lateral view of the left mandible. Chaetophractus vellerosus (Gray, 1865): 2, UNS CVEMAN1; 3, UNS CVEMA25; 4, UNS CVEHA22; 5, UNS CVEHAA4. Zaedyus pichiy (Desmarest, 1804): 6, UNS ZPMA51; 7, UNS ZPMA5; 8, UNS ZPHA7; 9, UNS ZPHA2 (an, angular process; con, condylar process; cor, coronoid process; mb, mandibular body; mf, mental foramina; $\mathrm{mn}$, mandibular notch; mr, mandibular ramus; rt, ridge for the insertion of the temporalis muscle; sm, scars for the insertion of the masseter muscle; tap, tip of the angular process). 


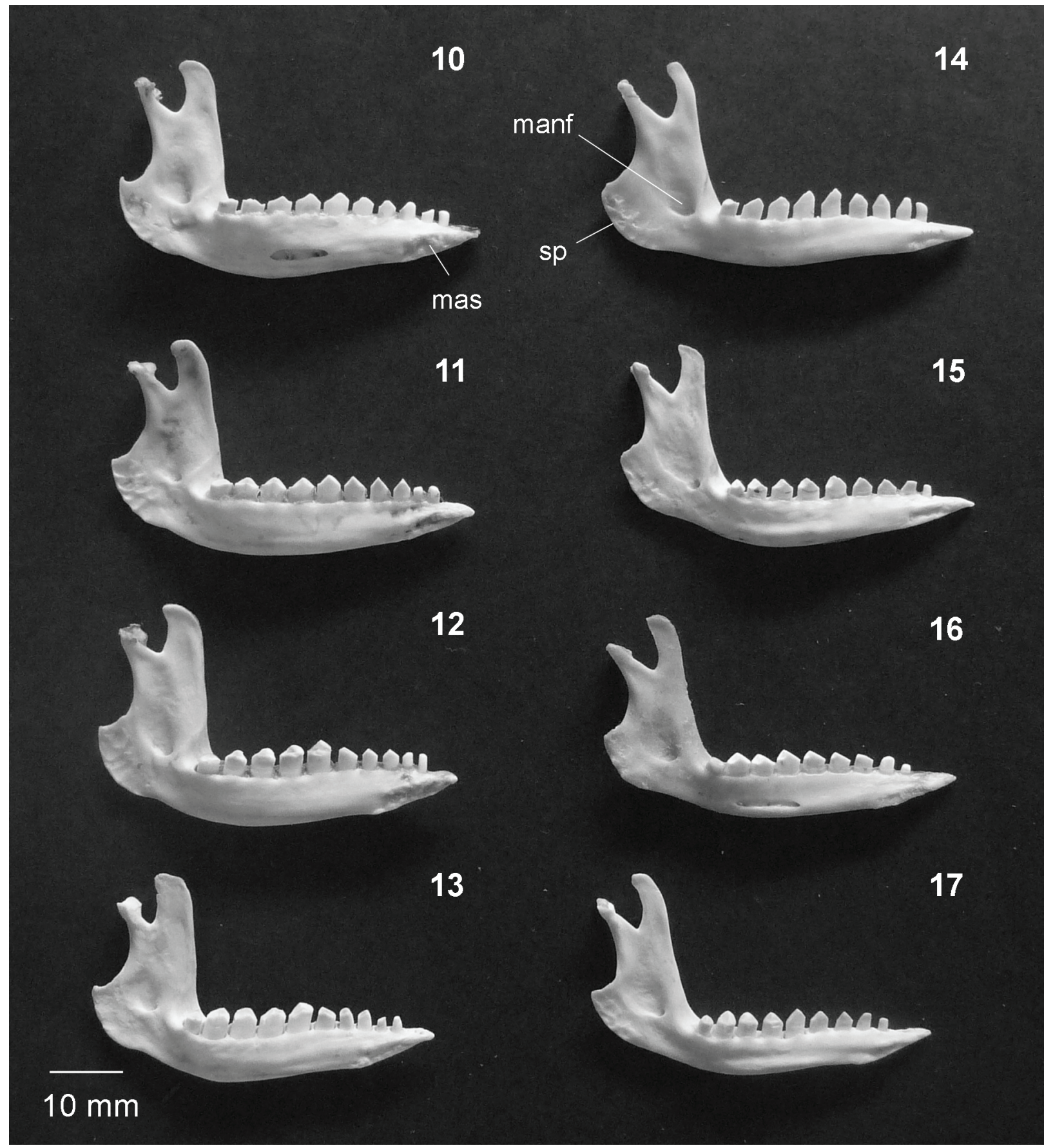

Figs 10-17. Medial view of the left mandible. Chaetophractus vellerosus (Gray, 1865): 10, UNS CVEMAN1; 11, UNS CVEMA25; 12, UNS CVEHA22; 13, UNS CVEHAA4. Zaedyus pichiy (Desmarest, 1804): 14, UNS ZPMA51; 15, UNS ZPMA5; 16, UNS ZPHA7; 17, UNS ZPHA2 (manf, mandibular foramen; mas, mandibular symphisis; sp, scars for the insertion of the pterygoid muscle).

the measured parameters. The ANCOVA between the length of the skull TLS (covariable) and TL did not detect differences between the slopes of the regression equations of both sexes $(p=0.63)$ nor a significant covariable $(\mathrm{p}=0.88)$. However significant differences were found between the intercept values of both sexes $(p=0.003)$. This indicated that part of the differences in the mandible size between males and females were independent of the possible differences in skull size between them. For Z. pichiy, sex differentiation was less clear (Tab. I).
The correlations between variables were generally low. In both species, the structure of the correlation matrices exhibited differences between sexes. For the screaming hairy armadillo, $39 \%$ of the coefficients (r) of the males and $11 \%$ of the coefficients of the females were significantly greater than zero; such significant $r$ values ranged from 0.60 to 0.83 in both genders. In the pichi, the statistically valid coefficients represented $32 \%$ in males and only $7 \%$ in females (r: 0.62 to 0.82 ).

In the PCA performed for the global sample, the first two components allowed explaining 70.3\% 

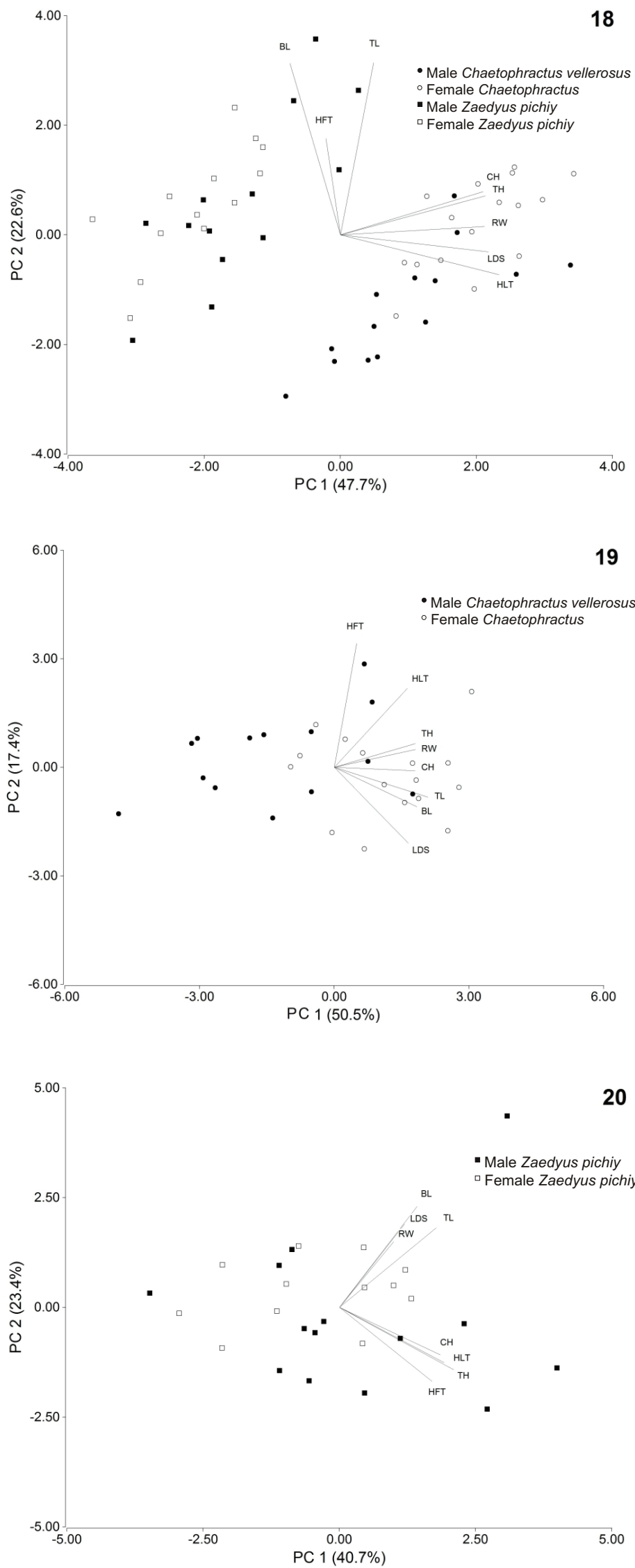

Figs 18-20. Biplot of the two first principal components PC1 and PC2 showing the distribution of the individuals: 18, total sample; 19, separate sexes of Chaetophractus vellerosus (Gray, 1865); 20, separate sexes of Zaedyus pichiy (Desmarest, 1804). Trait abbreviations in the text. 
Tab. I. Mean values \pm standard deviation ( $\mathrm{mm}$ ) for mandibular traits in total populations and separate sexes of Chaetophractus vellerosus (Gray, 1865 ) and Zaedyus pichiy (Desmarest, 1804). For each parameter, significant differences between species are indicated with different capital letters; different lowercases indicate differences between sexes of each species $(\mathrm{p} \leq 0.05)$ (N, number of individuals; TL, total length; LDS, length of the dental series; BL, body length; RW, ramus width; TH, total height; $\mathrm{CH}$, condylar height; HFT, height at the level of the first tooth; HLT, height at the level of the last tooth).

\begin{tabular}{|c|c|c|c|c|c|c|}
\hline \multirow[b]{2}{*}{ Trait } & \multicolumn{3}{|c|}{ Chaetophractus vellerosus (Gray, 1865) } & \multicolumn{3}{|c|}{ Zaedyus pichiy (Desmarest, 1804) } \\
\hline & $\begin{array}{c}\text { Total } \\
(\mathrm{N}=30)\end{array}$ & $\begin{array}{c}\text { Males } \\
(\mathrm{N}=14)\end{array}$ & $\begin{array}{l}\text { Females } \\
(\mathrm{N}=16)\end{array}$ & $\begin{array}{c}\text { Total } \\
(\mathrm{N}=26)\end{array}$ & $\begin{array}{c}\text { Males } \\
(\mathrm{N}=13)\end{array}$ & $\begin{array}{l}\text { Females } \\
(\mathrm{N}=13)\end{array}$ \\
\hline TL & $50.1 \pm 1.3 \mathrm{~A}$ & $49.3 \pm 1.3 \mathrm{a}$ & $50.9 \pm 0.9 \mathrm{~b}$ & $50.6 \pm 1.3 \mathrm{~A}$ & $50.8 \pm 1.4 \mathrm{a}$ & $50.5 \pm 1.3 \mathrm{a}$ \\
\hline LDS & $30.7 \pm 0.9 \mathrm{~A}$ & $30.2 \pm 0.6 \mathrm{a}$ & $31.2 \pm 0.8 \mathrm{~b}$ & $27.8 \pm 0.9 \mathrm{~B}$ & $27.8 \pm 1.1 \mathrm{a}$ & $27.7 \pm 0.8 \mathrm{a}$ \\
\hline BL & $34.0 \pm 0.7 \mathrm{~A}$ & $33.5 \pm 0.5 \mathrm{a}$ & $34.4 \pm 0.5 \mathrm{~b}$ & $35.1 \pm 1.0 \mathrm{~B}$ & $34.9 \pm 1.3 \mathrm{a}$ & $35.3 \pm 0.7 \mathrm{a}$ \\
\hline RW & $15.3 \pm 0.5 \mathrm{~A}$ & $15.1 \pm 0.5 \mathrm{a}$ & $15.5 \pm 0.6 \mathrm{~b}$ & $14.0 \pm 0.7 \mathrm{~B}$ & $14.0 \pm 0.8 \mathrm{a}$ & $14.1 \pm 0.4 \mathrm{a}$ \\
\hline $\mathrm{TH}$ & $27.9 \pm 1.2 \mathrm{~A}$ & $27.4 \pm 1.3 \mathrm{a}$ & $28.3 \pm 1.0 \mathrm{~b}$ & $26.3 \pm 1.2 \mathrm{~B}$ & $26.7 \pm 1.3 \mathrm{a}$ & $25.8 \pm 1.1 \mathrm{~b}$ \\
\hline $\mathrm{CH}$ & $23.3 \pm 1.1 \mathrm{~A}$ & $23.0 \pm 1.2 \mathrm{a}$ & $23.6 \pm 1.0 \mathrm{a}$ & $21.9 \pm 1.1 \mathrm{~B}$ & $22.0 \pm 1.3 \mathrm{a}$ & $21.8 \pm 0.9$ a \\
\hline HFT & $3.6 \pm 0.3 \mathrm{~A}$ & $3.6 \pm 0.4 \mathrm{a}$ & $3.6 \pm 0.2 \mathrm{a}$ & $3.8 \pm 0.3 \mathrm{~B}$ & $3.9 \pm 0.4 \mathrm{a}$ & $3.7 \pm 0.3 \mathrm{a}$ \\
\hline HLT & $8.2 \pm 0.3 \mathrm{~A}$ & $8.1 \pm 0.3 \mathrm{a}$ & $8.3 \pm 0.2 \mathrm{~b}$ & $6.5 \pm 0.5 \mathrm{~B}$ & $6.8 \pm 0.5 \mathrm{a}$ & $6.2 \pm 0.3 \mathrm{~b}$ \\
\hline
\end{tabular}

of the total between-group morphological variation (cophenetic correlation coefficient CPCC $=0.925$ ). An almost total segregation of both armadillos was evident on $\mathrm{PC} 1$, which represented $47.7 \%$ of the total variance (Fig. 18). Taking away the parameter LDS, which logically depends on the different number of teeth of both species, most of the differences between taxa seemed to be concentrated in the ramus and in the caudal part of the body. Although certain overlap of individuals was observed, C. vellerosus was more associated to mandibles taller and with wider body and ramus than the other species. The second component PC2, which accounted for $22.6 \%$ of the total variation, was less clear in separating species, although Z. pichiy was characterized by similar heavy loadings of this component on parameters of mandible length.

In the analysis of independent species, two components were retained for further analysis, which accounted for $67.9 \%(\mathrm{CPCC}=0.907)$ and $64.1 \%$ $(\mathrm{CPCC}=0.896)$ of the total variance in $C$. vellerosus and $Z$. pichiy, respectively. The intraspecific pattern of morphological variation was different in both species. For C. vellerosus, differentiation between sexes seemed to be the expression of a single size factor. A tendency to the segregation was observed along PC1 (50.5\% of the total variation), with females associated to greater values of mandible length, height and ramus width (Fig. 19). The opposite situation was observed for $Z$. pichiy, since no sexual segregation was evident on PC1 (40.7\% of the total variation) but on PC2 (23.4\% of the variance). This latter component loaded with different signs on two groups of measurements, one of mandible lengths (positive loadings) and the other of mandible heights (negative loadings) (Fig. 20). Thus, PC2 could be interpreted as a shape-type component, being females more associated to longer mandibles, and males more associated to taller ones.

For C. vellerosus, only one variable (BL) was selected to discriminate sexes, and the discriminant function obtained was $\mathrm{D}_{C v}=-142.4+4.2 \mathrm{BL}$, where $\mathrm{D}_{C v}<0$ for males and $\mathrm{D}_{C v}>0$ for females. The limit of classification (Lc) was $\mathrm{BL}=33.9$. This function correctly classified $83.3 \%$ of the sample $(85.7 \%$ of the males and $81.3 \%$ of the females). For Z. pichiy, the variables selected according to their discriminant power were, sequentially, HLT and BL. With the first variable, the discriminant function obtained was $\mathrm{D} 1_{Z p}=-24.7+$ 3.8 HLT, where $\mathrm{D} 1_{Z p}<0$ for females and $\mathrm{D} 1_{Z p}>0$ for males. The Lc was HLT $=6.5$. The percent of correct classification was of similar magnitude to that obtained in C. vellerosus ( $84.6 \%$ of both sexes). The two-variable model was described by the function $\mathrm{D} 2_{Z p}=27.1+4.5$ HLT $-1.7 \mathrm{BL}$, where $\mathrm{D} 2_{Z p}<0$ for females and D $2_{Z p}>0$ for males. The Lc was BL=16.2 + 2.9 HLT. In this case, the percent of total correct classification of the females was improved to $100 \%$.

\section{DISCUSSION}

The great diversity of forms recorded in the morphology of the mandibulodental complex of the extant and extinct Cingulata suggests diverse possibilities that seem to be the result of an adaptation to a wide dietary range (Vizcaíno et al., 2004; De Esteban-Trivigno, 2011). Although it has been demonstrated that it is not always possible to accurately predict diet on the basis of mandibular morphology (SMITH \& REDFORD, 1990), it is largely known the close relationship between them to the extent that comparison of morphology lead sometimes to useful predictions of dietary behaviour (VIzCAÍNO et al., 1998). Present armadillos, in particular, have different food preferences, ranging from herbivores to insectivores and carnivores, but they generally act as opportunistic omnivores that usually consume a wide variety of food items -insects and other invertebrates, plant material, small vertebrates, carrion -, depending probably on the relative abundance thereof (REDFORD, 1985).

Omnivorous feeding may be constrained by the ability of the animal to cope with disparate types of foods, and hence involves a commitment between the acquisition of jaw features which enable it to develop 
and apply the forces necessary to kill and dismember prey but also to grind plant matter. Morphological characteristics in the omnivore mandibles are hence more diverse than in carnivore and herbivore ones making it difficult to delineate a generalized pattern, as shown in some investigations (De Esteban-Trivigno, 2011). The mechanical design of the masticatory apparatus of $C$. vellerosus and $Z$. pichiy, as established in the present study, include: (a) an elevated jaw condyle with a slightly concave articular surface which fits in a deep but somewhat flattened glenoid fossa (unpublished), allowing some freedom of lateral movement of the lower jaw; (b) a well developed angular process; (c) a distinct coronoid process with a broad surface for the insertion of the temporalis muscle; (d) a tooth row extending to the rear end of the jaw behind the coronoid process; and (e) a tight junction, albeit without fusion, of the two dentaries at the symphysis. The elevated condyle high above the occlusal plane increases the moment arm of the masseteric and hence its mechanical advantage with respect to the temporalis (MAYNARD SMITH \& SAVAGE, 1959); the rearward extension of the tooth row maximizes bit force because this location is closer to the midline of the skull (GrEaves, 2002). On the other hand, the morphology of the condyle-glenoid fossa complex and the inferred good relative development of the masseter and the pterygoid (as indicated by the well developed and scarred angular process), summed to the dental morphology, suggest also that both species chew with a strong lateral component to the power stroke. Similar results were found by SMITH \& REDFORD (1990) for the yellow armadillo Euphractus sexcinctus, another member of the same group of armadillos.

Notwithstanding the similar mechanical design of the mandible of both studied species which confirm their generalized omnivory, differences arises that result in a more slender jaw configuration in Z. pichiy and a more massive one in C. vellerosus. In effect, the pichi is characterized by a general weakening of the lower jaw, with the dentary low and rostrally elongated tending to form a rod-like structure, the mandibular ramus thinner and leaning backward, a smaller coronoid process, an angular process less developed and a decrease in the number of teeth when compared with the screaming hairy armadillo. Several of these anatomical differences were reflected in the morphospace generated by the first two principal components in the PCA, with $C$. vellerosus tending to occupy the positive zone of the PC1 (defined by higher values of mandible height, and ramus and body width) and Z. pichiy tending to locate in the positive zone of the PC2 (defined mainly by higher values of mandible length). The morphological characteristics found in the masticatory apparatus of $Z$. pichiy have been traditionally linked with insectivorous diets (REDFORD, 1987; SMITH \& RedFord, 1990; ReIss, 2000; Michaux et al., 2007; De Esteban-Trivigno, 2011). Such characteristics maximize the grasping and piercing function necessary to crush arthropod exoskeletons, which require lower occlusal force than required to grind, for example, vegetal matter (Michaux et al., 2007). These findings suggest that, although both species are opportunistic omnivores, the masticatory apparatus of the pichi would be more adapted to consume invertebrates than that of the screaming hairy armadillo, and this could lay to a reduction in interspecific competition between coexisting populations of both taxa. Unfortunately, available studies on food preferences of these species (e.g. Greegor, 1980; SoIBELzon et al., 2007; SUPERINA et al., 2009) do not allow substantiating our results. However, some support in favour of this hypothesis may come from the comparison of the mandible of $Z$. pichiy with that of the long-nosed armadillos of the genus Dasypus, which have been also indicated as non-selective opportunistic feeders (BREECE \& DUSI, 1985 ) but with a strong component of insectivory (mainly myrmecophagy) (TALMage \& Buchanan, 1954; Redford, 1985; SMith \& Redford, 1990; DA Silveira Anacleto, 2007; Abba \& Cassini, 2010). Excepting by the condylar height and the number of teeth (both reduced in the long-nosed armadillos), the general configuration of the mandible of these species show noticeable similarities; whether this "insectivore" morphotype can be considered as derivative or not for armadillos seems to be a controversial matter in light of the contradictory results of the major phylogenetic studies conducted to date (e.g. EngelmanN, 1985; Delsuc et al., 2002; Gaudin \& WiBle, 2006).

Intra- (sexual) specific differences were observed in the mandible of both $C$. vellerosus and Z. pichiy, though they were not very marked, suggesting only minor differences, if any, in the feeding habits of males and females. Part of the differences between sexes was obvious from the correlation structure of mandible parameters. In general, the correlation values were low because only adult animals were used. In the early stages of growth, many mammals are characterized by the highest values of correlation coefficients between skull dimensions, and a progressive decrease in the reciprocal correlations with increasing age occurs (BUCHALCZYK \& RUPRECHT, 1977; KobryŃCZUK \& RosKosZ, 1980). Such tendency may be differential between male and female mammals, indicating more isometric growth in one sex than in the other (KoBRYŃcZuK \& Roskosz, 1980). In our case, the trend to a synchronism in the growth of the mandible resulting in a more stable shape seems to be preserved in adult males to a larger extent than in females for both species.

The pattern of inter-sexual variation was different in every case. In $C$. vellerosus, both the univariate and multivariate analysis indicated a size-based differentiation of sexes, with females larger than males. Similar results were found by SQUARCIA et al. (2009) for another Chaetophractus species, C. villosus. By 
contrast, the differences between genders of $Z$. pichiy did not involve an absolute size factor, but males characterized by taller mandibles and females by longer ones. Sexual dimorphism implied thereby a shapebased differentiation of sexes, and such variability was expressed by the second component PC2 in the PCA.

The high percentages of right classification of sexes provided by the discriminant functions obtained in the present study (higher than $80 \%$ in all cases), makes them suitable tools for sex assignment to specimens of unknown sex with a minimum effort, since only one measurement is needed (BL for the screaming hairy armadillo, HLT for the pichi). The inclusion of a new variable $(\mathrm{BL})$ in the case of $Z$. pichiy improved notoriously the classification of the females $(100 \%)$ and hence the choice of the most adequate model should be decided by balancing the effort required and the desired degree of accuracy. It is worth noting that, since the discriminant technique is very sensitive to the intrinsic properties of populations, the functions obtained should be applied only to samples composed by adult individuals which come from the same study area. This is particularly critical in the case of Z. pichiy, to whom two subspecies have been described: Z. pichiy pichiy (Desmarest, 1804) and Z. pichiy caurinus Thomas, 1928. The former distributes in the Pampas of eastern and southeastern Argentina, whereas Z. p. caurinus occurs in eastern Chile and western Argentina, from the province of Mendoza south into Nahuel Huapi (Wetzel et al., 2007). As Squarcia \& CaSanave (1999) determined, there exist significant cranial differences between both subspecies, Z. p. caurinus being characterized by a smaller skull than Z. p. pichiy. In the present study, only individuals of the latter subspecies were used.

Variations in the basic number of mandibular teeth (10 for the screaming hairy armadillo, 9 for the pichi) may be a common phenomenon within dasypodids. Wible \& GAUDIN (2004) described in adult specimens of $E$. sexcinctus the existence of small anterior unilateral or bilateral openings which are in line with the tooth row behind it, although if they are ever occupied or not was unknown. STANGL et al. (1995) recorded deviation from the normal $8 / 8$ dental formula in $D$. novemcinctus, which they attributed to tooth loss as a natural event relative to age, but also to congenital anomalies that result in supernumerary or fewer teeth. In our case, although both types of aberrant dental conditions (extra and fewer teeth) were observed in the pichi, only the second one (fewer teeth) could be verified in the screaming hairy armadillo. In all cases of lack of teeth, the deposit of bone filling the alveoli confirmed that corresponded to unerupted teeth instead of being a natural teeth loss, unless such loss had occurred long time ago during earlier growing stages. Unilateral aberrancies seem to be more common than bilateral ones in both species, but extra sampling effort should be made to corroborate this matter.
Acknowledgements. The authors thank the statistical advice by Prof. R. Camina, and the helpful comments on the manuscript by Dr. S. Squarcia. Financial support by the Secretaría General de Ciencia y Tecnología, Universidad Nacional del Sur (Project PGI 24/B152) is also acknowledged.

\section{REFERENCES}

AbBA, A. M. \& CAssini, M. H. 2010. Ecological differences between two sympatric species of armadillos (Xenarthra, Mammalia) in a temperate region of Argentina. Acta Theriologica 55(1):35-44.

AbBa, A. M. \& Vizcaíno, S. F. 2011. Distribución de los armadillos (Xenarthra: Dasypodidae) en la provincia de Buenos Aires, Argentina. Mastozoología Neotropical 18(2):185-206.

Breece, G. A. \& Dusi, J. L. 1985. Food habits and home ranges of the common long-nosed armadillo Dasypus novemcinctus in Alabama. In: Montgomery, G. G. ed. The Evolution and Ecology of Armadillos, Sloths and Vermilinguas. Washington, D. C., Smithsonian Institution, p. 419-427.

BuCHALCZYK, T. \& Ruprecht, A. L. 1977. Skull variability of Mustela putorius Linnaeus, 1758. Acta Theriologica 22(1-8):87-120.

DA Silveira Anacleto, T. C. 2007. Food habits of four armadillo species in the Cerrado Area, Mato Grosso, Brazil. Zoological Studies 46(4):529-537.

De Esteban-Trivigno, S. 2011. Ecomorfología de xenartros extintos: análisis de la mandíbula con métodos de morfometría geométrica. Ameghiniana 48(3):381-398.

De Iuliis, G.; Bargo, M. S. \& Vizcaíno, S. F. 2001. Variation in skull morphology and mastication in the fossil giant armadillos Pampatherium spp. and allied genera (Mammalia: Xenarthra: Pampatheriidae), with comments on their systematics and distribution. Journal of Vertebrate Paleontology 20(4):743-754.

Delsuc, F.; Scally, M.; Madsen, O.; Stanhope, M. J.; De Jong, W. W.; Catzeflis, F. M.; Springer, M. S. \& Douzery, E. J. P. 2002. Molecular phylogeny of living xenarthrans and the impact of character and taxon sampling on the placental tree rooting. Molecular Biology and Evolution 19(10):1656-1671.

EngelmanN, G. F. 1985. The phylogeny of the Xenarthra. In: Montgomery, G. G. ed. The Evolution and Ecology of Armadillos, Sloths and Vermilinguas. Washington, D. C., Smithsonian Institution, p.51-63.

FERIGOLO, J. 1985. Evolutionary trends of the histological pattern in the teeth of Edentata (Xenarthra). Archives of Oral Biology 30(1):71-82.

Gaudin, T. J. \& Wible, J. R. 2006. The phylogeny of living and extinct armadillos (Mammalia, Xenarthra, Cingulata): A craniodental analysis. In: Carrano, M. T.; Gaudin, T. J.; Blob, R. W. \& Wible, J. R. eds. Amniote Paleobiology: Perspectives on the Evolution of Mammals, Birds and Reptiles. Chicago, University of Chicago Press, p. 153-198.

Greaves, W. S. 2002. Modeling the distance between the molar tooth rows in mammals. Canadian Journal of Zoology 80(2):388-393.

GreEgOR, D. H. JR. 1980. Diet of the little hairy armadillo, Chaetophractus vellerosus, of northwestern Argentina. Journal of Mammalogy 61(2):331-334.

InFoStat. 2006. Grupo InfoStat, FCA, Universidad Nacional de Córdoba, Argentina.

JeNNRICH, R. \& SAMPSON, P. 1983. Stepwise discriminant analysis. In DIXON, W. J. ed. BMDP statistical software. Berkeley, University of California Press, p. 519-537.

KobryŃczuK, F. \& Roskosz, T. 1980. Correlation of skull dimensions in the European bison. Acta Theriologica 25:349-363.

Maynard Smith, J. \& Savage, R. J. G. 1959. The mechanics of mammalian jaws. School Science Review 141:289-301.

Michaux, J.; Chevret, P. \& Renaud, S. 2007. Morphological diversity of Old World rats and mice (Rodentia, Muridae) mandible in relation with phylogeny and adaptation. Journal of Zoological Systematics and Evolutionary Research 45(3):263-279.

REDFORD, K. H. 1985. Food habits of Armadillos (Xenarthra: Dasypodidae). In: Montgomery, G. G. ed. The Evolution and Ecology of Armadillos, Sloths and Vermilinguas. Washington, D. C., Smithsonian Institution, p. 429-437.

1987. Ants and termits as food: Patterns of mammalian myrmecophagy. In: Genoways, H. H. ed. Current Mammalogy. New York and Londres, Plenum Press. v. 1, p. 349-399. 
RedFord, K. H. \& EisenBerg, J. F. 1992. Order Xenarthra (Edentata): Family Dasypodidae. In: RedFord, K. H. \& EIsenberG, J. F. eds. Mammals of the Neotropics. Chicago, University of Chicago Press. v. 2, p. 52-68.

ReISs, K. Z. 2000. Feeding in myrmecophagous mammals. In Schwenk, K. ed. Feeding: Form, Function and Evolution in Tetrapod Vertebrates. San Diego, Academic Press, p. 459-485.

Smith, K. K. \& RedFord, K. H. 1990. The anatomy and function of the feeding apparatus in two armadillos (Dasypoda): anatomy is not destiny. Journal of Zoology 222:27-47.

Soibelzon, E.; Daniele, G.; Negrete, J.; Carlini, A. A. \& Plischuk, S. 2007. Annual diet of the little hairy armadillo, Chaetophractus vellerosus (Mammalia, Dasypodidae), in Buenos Aires Province, Argentina. Journal of Mammalogy 88(5):1319-1324.

Squarcia, S. M. \& Casanave, E. B. 1999. Discriminación entre las subespecies de Zaedyus pichiy (Desmarest, 1804) (Mammalia, Dasypodidae), utilizando caracteres morfométricos craneanos. Physis, Sección C 57(132-133):19-24.

Squarcia, S. M.; Sidorkewicu, N. S. \& Casanave, E. B. 2006. Cranial osteology of the armadillo Chaetophractus villosus (Mammalia, Xenarthra, Dasypodidae). International Journal of Morphology 24(4):541-547.

Squarcia, S. M.; Sidorkewicj, N. S.; Camina, R. \& Casanave, E. B. 2009. Sexual dimorphism in the mandible of the armadillo Chaetophractus villosus (Desmarest, 1804) (Dasypodidae) from northern Patagonia, Argentina. Brazilian Journal of Biology 69(2):347-352.

Stangl, F. B. Jr.; Beauchamp, S. L. \& Konermann, N. G. 1995. Cranial and dental variation in the nine-banded armadillo,
Dasypus novemcinctus, from Texas and Oklahoma. The Texas Journal of Science 47(2):89-100.

Superina, M.; Fernández Campón, F.; Stevani, E. L. \& Carrara, R. 2009. Summer diet of the pichi Zaedyus pichiy (Xenarthra: Dasypodidae) in Mendoza Province, Argentina. Journal of Arid Environments 73(6-7):683-686.

Talmage, R. V. \& Buchanan, G. D. 1954. The armadillo (Dasypus novemcinctus): A review of its natural history, ecology, anatomy and reproductive phisyology. The Rice Institute Pamphlet 41(2): $1-135$

Vizcaíno, S. F.; Bargo, M. S. \& CASSINI, G. H. 2006. Dental occlusal surface area in relation to body mass, food habits and other biological features in fossil xenarthrans. Ameghiniana 43(1):1126.

Vizcaíno, S. F.; De Iuliis, G. \& Bargo, M. S. 1998. Skull shape, masticatory apparatus, and diet of Vassallia and Homelsina (Mammalia: Xenarthra: Pampatheriidae): When anatomy constrains destiny. Journal of Mammalian Evolution 5(4):291-322.

Vizcaíno, S. F.; Farina, R. A.; Bargo, M. S. \& De Iuliis, G. 2004. Functional and phylogenetic assessment of the masticatory adaptations in Cingulata (Mammalia: Xenarthra). Ameghiniana 41(4):651-664.

Wetzel, R. M.; Gardner, A. L.; Redford, K. H. \& Eisenberg, J. F. 2007. Order Cingulata. In: Gardner, A. L. ed. Mammals of South America: Marsupials, Xenarthrans, Shrews, and Bats. Chicago, University of Chicago Press. v. 1, p. 128-156.

Wible, J. R. \& Gaudin, T. J. 2004. On the cranial osteology of the yellow armadillo Euphractus sexcinctus (Dasypodidae, Xenarthra, Placentalia). Annals of Carnegie Museum 73(3):117-196. 